\title{
Gjörgæslusjúklingar með inflúensu A (H1N1) á Íslandi 2009
}

Gísli $\mathbf{H}$. Sigurðsson ${ }^{1,4}$

svæfinga- og gjörgæslulæknir,

Alma D. Möller ${ }^{1}$ svæfinga- og gjörgæslulæknir

Bjarki

Kristinsson ${ }^{1}$ læknir

Ólafur

Guðlaugsson ${ }^{2,3}$

smitsjúkdómalæknir

Sigurbergur

Kárason ${ }^{1}$

svæfinga- og gjörgæslulæknir

Sigurður E. Sigurðsson ${ }^{5}$

svæfinga- og gjörgæslulæknir

Már

Kristjánsson ${ }^{2}$

smitsjúkdómalæknir

Kristinn

Sigvaldason ${ }^{1}$

svæfinga- og gjörgæslulæknir

Lykilorð: inflúensa $\mathrm{A}$, lungnabólga, fjölliffærabilun,

dánartíðni, faraldsfræði, giörgæsla, öndunarvélameðferð, ECMO.

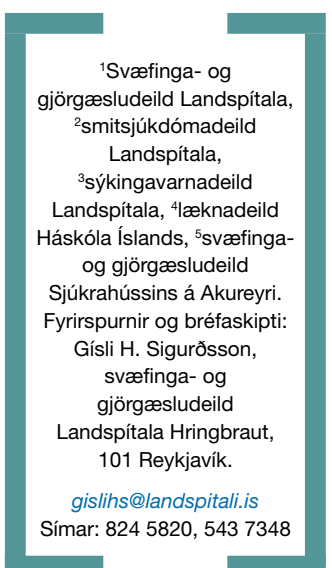

\section{Ágrip}

Tilgangur: Að lýsa helstu einkennum og afdrifum peirra sem lögðust inn á gjörgæsludeildir á Íslandi vegna inflúensusýkingar af A stofni (H1N1) haustið 2009.

Aðferðir: Aflað var upplýsinga um sjúklinga sem lögðust inn á gjörgæsludeildir á Íslandi með staðfesta H1N1 2009 sýkingu.

Niðurstöður: 16 sjúklingar lögðust inn á gjörgæsludeildir vegna inflúensu A (H1N1) sýkingar, meðalaldur 48 ár (1-81). Flestir töldust vera tiltölulega frískir fyrir, en 13 höfðu pó sögu um reykingar, offitu eða háprýsting. 15 höfðu hita, hósta, öndunarpyngsli og dreifðar íferðir í báðum lungum á lungnamynd og margir fengu fjöllíffærabilun. Allir fengu veirulyf og 12 voru meðhöndlaðir í öndunarvél, par af tveir einnig í hjarta- og lungnavél. Enginn sjúklingur lést á gjörgæsludeild, en einn fjölveikur aldraður sjúklingur lést síðar á legudeild.

Ályktanir: (1) Tíðni alvarlegra sjúkdómseinkenna af völdum inflúensu A (H1N1) sem leiða til gjörgæslumeðferðar er há á Íslandi. (2) Pessir sjúklingar fá flestir, auk annarra líffæratruflana, mjög alvarlega öndunarbilun sem oft lætur ekki undan hefðbundinni öndunarvélameðferð. (3) Árangur meðferðar á íslenskum gjörgæsludeildum hefur verið góður. (4) Niðurstöður pessarar rannsóknar geta nýst yfirvöldum við mat á meðferðarmöguleikum og fyrirbyggjandi aðgerðum gegn pessum lífshættulega sjúkdómi.

\section{Inngangur}

Inflúensuveiran er orthomyxoveira og skiptist í prjá flokka, A, B og C. Flokkar A og B valda sjúkdómum í mönnum. Inflúensa A er pekkt fyrir pað hvað hún á auðvelt með að breyta sér. Раð er tvennt sem veldur. Annars vegar ónákvæmni í RNA polymerasanum sem myndar ný stökkbreytt afbrigði veirunnar. Ef pað er nægilega frábrugðið til að víkja sér undan ónæmissvari gegn móðurveirum getur pað orðið að næsta árstíðabundna faraldursstofni. Pessar breytingar stafa af sameindalegri breytingu í hæmagglútíni (H) og eða neuramídasa (N) sem eru eggjahvítusameindir (væki) á yfirborði veirunnar og flokkun peirra byggir á. Hins vegar geta genabútar veirunnar (1 til 8 ) endurraðast. Pá myndast alveg ný veira sem enginn hefur verndandi mótefni gegn og forsenda fyrir heimsfaraldri verður til. ${ }^{1,2}$ Nýja veiran ber $\mathrm{H}$ og/ eða $\mathrm{N}$ væki sem ekki hafa verið í dreifingu meðal fólks lengi/áður.

Heimsfaraldur inflúensu hefur geisað fjórum sinnum á síðastliðnum hundrað árum og í hvert sinn stafað af inflúensuveiru af A flokki. ${ }^{3,4}$ Spánska veikin (H1N1) 1918 var peirra skæðust, en hún olli tugum milljóna dauðsfalla. Á Íslandi létust tæplega 500 manns á sex vikum sem faraldurinn geisaði og var talið að dánarhlutfall peirra sem sýktust hafi verið 2,6\%. ${ }^{5}$ Asíuinflúensan árið 1957 (H2N2) og Hong Kong inflúensan árið 1968 (H3N2) ollu vægari faröldrum. ${ }^{5}$ раð sem einkenndi pessa heimsfaraldra var að ungt fólk umfram aldraða voru fórnarlömbin. ${ }^{6}$ Í mars 2009 varð svokallaðrar svínainflúensu fyrst vart í kjölfar faraldurs af alvarlegum lungnasýkingum í Mexíkó ${ }^{7}$ og í tveimur börnum í Bandaríkjum Norður-Ameríku. ${ }^{8}$ Petta er ný inflúensuveira af A flokki sem reynist vera upprunnin í svínum með samruna tveggja veira, en báðar eiga rætur að rekja til veirunnar sem olli spænsku veikinni 1918. ${ }^{9} 10$ Hún dreifðist skjótt til allra heimsálfa og lýsti WHO yfir heimsfaraldursástandi af stigi sex pann 11. júní 2009.

Á Íslandi greindist fyrsta tilfellið 23. maí 2009 og voru fyrstu sjúklingarnir lagðir inn á sjúkrahús 23. september sama ár. Í byrjun var faraldurinn í hægum gangi og flest tilfellin tengd ferðalögum erlendis. Er leið á ágústmánuð færðist hann í aukana, náði fullum krafti síðustu vikuna í september og hámarki um miðjan október síðastliðinn, en hefur verið í rénun síðan. ${ }^{11}$

Nokkrar vísindagreinar hafa pegar birst um heimsfaraldurinn, meðal annars frá Mexíkó, ${ }^{12}$ Ástralíu og Nýja-Sjálandi ${ }^{13}$ og Kanada. ${ }^{14}$ Í pessum greinum er alvarlegustu tilfellunum lýst, pað er peim sem lögðust inn á gjörgæsludeildir. Niðurstöður rannsóknanna benda til að ungt fólk verði einkum fyrir sýkingunni, flestir 


\section{Fjöldi innlagna á gjörgaeslu}

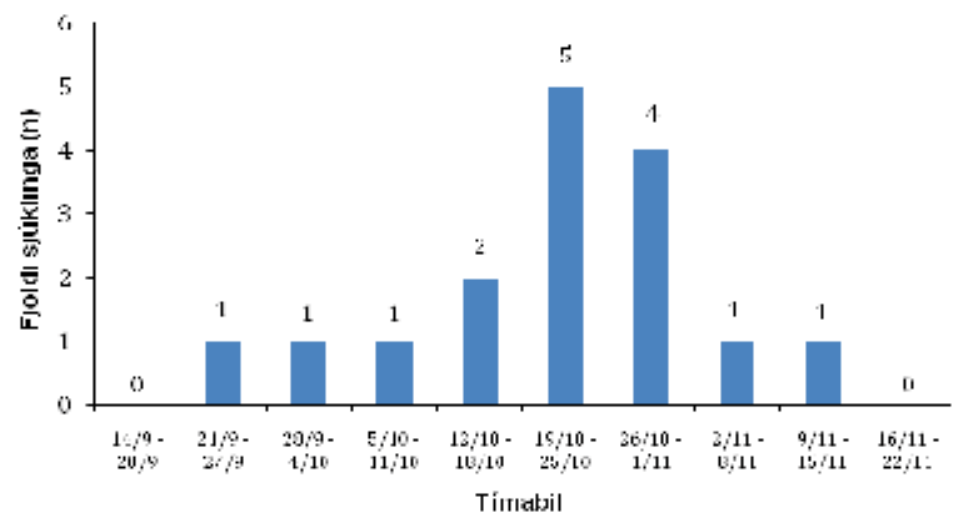

Mynd 1. Innlagnir sjúklinga með H1N1 inflúensusýkingu á gjörgæsludeildir Landspitala og Sjúkrahússins á Akureyri.

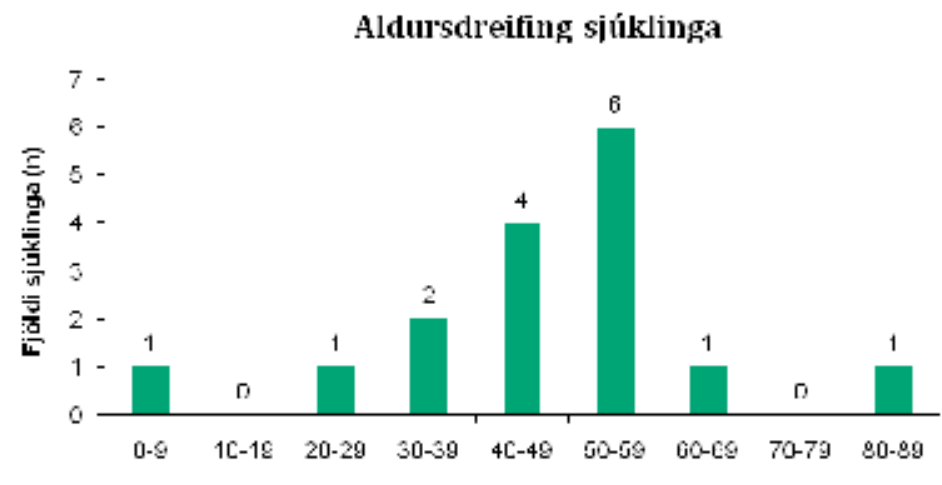

Alcursbilı àrum

Mynd 2. Aldursdreifing sjúklinga með H1N1 inflúensu á gjörgæsludeildum á Landspítala og Sjúkrahúsinu á Akureyri.
Allir sjúklingar sem lögðust inn á einhverja ofangreindra gjörgæsludeilda (börn og fullorðnir) vegna staðfestrar inflúensu A (H1N1) á tímabilinu 23. maí til 1. desember 2009 voru teknir með í rannsóknina. Inflúensa A (H1N1) var staðfest með fjölliðunarhvarfi (reverse transcriptasepolymerase chain reaction, RT-PCR) hjá öllum sjúklingunum.

Upplýsingum um eftirfarandi var safnað úr sjúkraskrá: aldur, kyn, hæð, pyngd, sjúkrahús, sjúkdómsgreiningu, undirliggjandi sjúkdóma, líkamshita, blóðprýsting, hjartsláttarhraða, öndunartíðni, önnur flensueinkenni, súrefnispörf, blóðgös, blóðsölt, nýrnastarfsemi, blóðgildi, aðrar sýkingar í gjörgæslulegu, niðurstöður ræktana, tíma frá fyrstu einkennum að innlögn, legutíma á gjörgæslu, legutíma á spítala, dánarorsök, dánardægur, fylgikvilla (fjöllíffærabilun, sýklasóttarlost, blæðingar) og meðferð með veirulyfjum (oseltamivir eða zanamivir), öðrum sýklalyfjum, næringu, öndunarvél, æðavirkum lyfjum og blóðskilun. Alpjóðleg matskerfi, APACHE II skor (acute physiology and chronic health score), SAPS II skor (simplified acute physiology score), RIFLE skor (risk, injury, failure, loss of kidney function, end stage kidney disease score) og SOFA skor (sequential organ failure assessment), voru notuð til mats á alvarleika veikinda sjúklinganna. ${ }^{15}$

Eftirfarandi teljast undirliggjandi sjúkdómar í rannsókninni: alvarlegur kransæðasjúkdómur, langvinn hjartabilun, lungnabilun, lifrarbilun eða nýrnabilun, sjúkdómar í heilaæðum, sykursýki, offita (líkamspyngdarstuðull (BMI) >30), krabbamein eða langvinn ónæmisbælandi meðferð. Upplýsingar um háprýsting, reykingar, pungun eða barnsburð innan 30 daga frá upphafi veikinda voru skráðar.

Meginendapunktur rannsóknarinnar var andlát innan 28 daga frá greiningu, en afleiddir endapunktar voru tími í öndunarvél, legutími á gjörgæsludeild og legutími á sjúkrahúsi.

Tölfræði og úrvinnsla gagna: Notast var við einfalda lýsandi tölfræði. Meðalgildi og staðaldreifing voru notuð um breytur með normaldreifingu en miðgildi og dreifing fyrir hinar.

\section{Niðurstöður}

Frá 25. september til 8. nóvember 2009 lögðust 16 sjúklingar inn á gjörgæsludeildir á Íslandi vegna lungnabólgu og staðfestrar inflúensu A (H1N1) sýkingar (mynd 1 og tafla I). Peir höfðu að meðaltali verið veikir í prjá og hálfan dag fyrir innlögn á sjúkrahús og legið á sjúkrahúsi einn sólarhring fyrir innlögn á gjörgæsludeild (tafla I). Sex sjúklingar voru lagðir beint inn á gjörgæsludeild við komu 
á sjúkrahús. Meðalaldur sjúklinganna var 47,5 ár (1-81) en flestir sjúklinganna voru á aldrinum 30-60 ára (mynd 2). Á pessu tímabili lögðust 170 sjúklingar inn á sjúkrahús á Íslandi með einkenni um svínaflensu, par af helmingur með staðfesta inflúensu A (H1N1). Sjúklingar með staðfesta inflúensu og sem purftu gjörgæslumeðferðar við voru pví um $20 \%$ af sjúklingum sem lögðust inn með staðfesta inflúensu, eða $10 \%$ af öllum innlögnunum vegna inflúensu, sem er svipað hlutfall og lýst hefur verið erlendis. ${ }^{12,13}$ Alls hafa 8650 einstaklingar með inflúensulík einkenni eða jákvætt RT-PCR leitað til heilbrigðispjónustunnar á pessu tímabili, en talið að um 60-100 púsund tilfelli sýkingarinnar hafi verið á landinu öllu. ${ }^{16}$

Flestir sem lögðust á gjörgæsludeildir töldust vera frískir fyrir pessi veikindi en $81 \%$ voru með undirliggjandi áhættupætti. Reykingar, offita og háprýstingur voru mest áberandi (tafla II). Engin ófrísk kona var meðal sjúklinganna.

Allir nema einn $(15 / 16)$ voru með einkenni hita, hósta og öndunarpyngsla og útbreidda lungnabólgu á röntgenmynd af lungum, en einn sjúklingur var lagður inn í kjölfar krampa (mynd 3). Áberandi einkenni var mikið og seigt slím 1 berkjum, einkum er leið á veikindin. Meirihluti sjúklinga (11 af 16) purfti meðferð vegna losts og fjórir fengu bráða nýrnabilun eða önnur einkenni um fjöllíffærabilun (tafla III). Algengt var að sjá brenglun á blóðmynd sjúklinga við innlögn. Kreatínkínasi var mældur hjá sjö sjúklingum og reyndist hækkaður hjá peim öllum (125-2900 $\mathrm{U} / \mathrm{L}$ ).

Allir sjúklingarnir fengu oseltamivir eða zanamivir frá komu (tafla IV). Reynd var meðferð með ytri öndunarvél (BiPAP (Bi-level Positive Airway Pressure), Respironics $($ ) hjá fjórum sjúklingum, en hún reyndist ófullnægjandi hjá premur peirra og voru peir í framhaldinu svæfðir og lagðir í öndunarvél. Alls voru 12 sjúklingar meðhöndlaðir í öndunarvél. Margir sjúklinganna voru með svo alvarlegar lungnabreytingar að péttni lungna á röntgenmynd eða ómun af lungum var sambærileg og á lifur (mynd 3). Prír voru meðhöndlaðir í grúfulegu í öndunarvél, einn með níturoxíð innöndun (nitric oxide) og tveir 1 hjarta- og lungnavél (extra corporeal membrane oxygenation; ECMO) (tafla IV). Einn sjúklingur fékk krampa án pess að vera með fyrri sögu um flogaveiki.

Meðal APACHE II skor sjúklinganna var 20 sem sýnir að peir voru mjög veikir (tafla I) og samkvæmt pví með áætlaða dánartíðni um 35\%. Enginn sjúklingur lést á gjörgæsludeild, en einn fjölveikur sjúklingur á níræðisaldri lést af völdum alvarlegs grunnsjúkdóms á legudeild eftir útskrift
Tafla I. Upplýsingar um sjúklinga og tímapættir í veikindum peirra. Gildi eru ýmist gefin upp sem meðaltal ( \pm staðalfrávik) eða miðgildi (ásamt hæsta og lægsta gildi). Fyrir sjúkling sem var enn inniliggjandi 12. janúar 2010 var heildarlegutími hans reiknaður frá innlögn til pess dags.

\begin{tabular}{lc} 
Upplýsingar um sjúklinga og legutími & gildi \\
\hline Fjöldi sjúklinga & 16 \\
\hline karlar & $12(75 \%)$ \\
\hline Meðalaldur (miðgildi) & $48(1-81)$ \\
\hline Líkamspyngdarstuðull (meðaltal) & $31,3 \pm 6,48$ \\
\hline APACHE II* & $20,0 \pm 10,8$ \\
\hline SAPS II** & $33,9 \pm 22,4$ \\
\hline Dagar frá upphafi einkenna að innlögn á sjúkrahús & $3,5(0-11)$ \\
\hline Dagar frá innlögn á sjúkrahús að innlögn á gjörgæslu & $1(0-6)$ \\
\hline Legudagar á gjörgæslu & $9,5(1-57)$ \\
\hline Heildarlegutími á sjúkrahúsi & $15,5(3-72)$
\end{tabular}

* APACHE II = Acute Physiology and Chronic Health Evaluation II

** SAPS II = Simplified Acute Physiology Score II

Tafla II. Undirliggjandi sjúkdómar og aðrir áhættupættir.

\begin{tabular}{|c|c|c|}
\hline Áhættupættir & $\mathrm{n}$ & $\%$ \\
\hline Saga um reykingar & 9 & $56 \%$ \\
\hline Offita ( $\geq 30 \mathrm{BMI})$ & 8 & $50 \%$ \\
\hline Háprýstingur & 7 & $44 \%$ \\
\hline Geðlyf & 6 & $38 \%$ \\
\hline Hjartasjúkdómar & 3 & $19 \%$ \\
\hline Langvarandi lungnasjúkdómar & 3 & $19 \%$ \\
\hline Sykursýki & 2 & $13 \%$ \\
\hline Engir undirliggjandi sjúkdómar & 3 & $19 \%$ \\
\hline
\end{tabular}

Tafla III. Fylgikvillar.

\begin{tabular}{lc}
\hline Fylgikvillar & $\mathrm{n}(\%)$ \\
\hline SOFA* skor & $6,9 \pm 3,3$ \\
\hline $\begin{array}{l}\text { Bráður nýrnaskaði skv RIFLE } \\
\text { skilmerkjum }\end{array}$ & $4(25 \%)$ \\
\hline Áhætta (Risk) & $1(6,25 \%)$ \\
\hline Skaði (Injury) & 0 \\
\hline Bilun (Failure) & $1(6,25 \%)$ \\
\hline Tap (Loss) & $2(12,5 \%)$ \\
\hline Lost & $11(69 \%)$ \\
\hline Síðkomin lungnabólga & $3(19 \%)$ \\
\hline Blóðmynd & $8(50 \%)$ \\
\hline Lækkun á blóðflögum( $\left.<150 \times 10^{\%} / L\right)$ & $13(81 \%)$ \\
\hline Lækkun á eitilfrumum(<1,1 x 10\%/L ) & \\
\hline
\end{tabular}

*SOFA = Sequential Organ Failure Assessment score.

${ }^{\star}$ RIFLE = Risk, Injury, Failure, Loss, and End-stage Kidney (RIFLE) classification.

frá gjörgæsludeild. Pegar petta er skrifað eru allir sjúklingarnir útskrifaðir af sjúkrahúsinu. Sá sem lá lengst var í sjö vikur á gjörgæsludeild, par af fjórar vikur í ECMO-meðferð og 12 vikur á sjúkrahúsinu. 
Mynd 3. Péttar iferđir í bádum lungum sjúklings með H1N1 inflúensulungnabólgu og brátt andnaudarheilkenni (acute respiratory distress syndrome, ARDS). Mjög litil loftun er ílungunum og péttleiki peirra virðist lítt minni en yfir lifur.

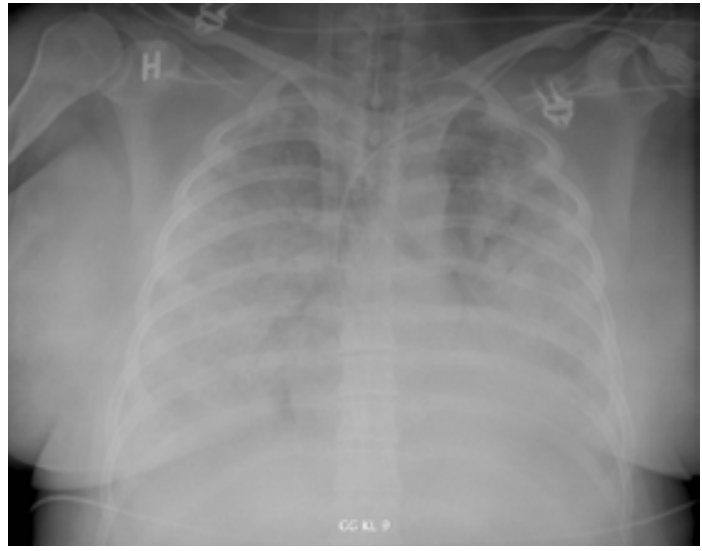

\section{Umræður}

Fyrsti heimsfaraldur inflúensu í 41 ár hefur nú stungið upp kollinum. Hans varð fyrst vart í Mexíkó og Bandaríkjunum í mars 2009. Á stuttum tíma náði hann að dreifast um meirihluta heimsins prátt fyrir að á norðurhveli jarðar væri hið hefðbundna flensutímabil að líða undir lok. Fyrsta tilfellið barst til Íslands 23. maí 2009 pó ekki fylgdu pví mikil veikindi. Faraldurinn náði að valda umtalsverðum veikindum meðal annars í Kanada og Bandaríkjunum og á suðurhveli

Tafla IV. Nokkur atriði meðferðar sjúklinga með H1N1 sýkingu á giörgæslu. Algengasti skammtur af oseltamivir var $150 \mathrm{mg} /$ dag en 4 sjúklingar fengu háskammtameðferð(300mg/dag). Skammtur af zanamivir var $20 \mathrm{mg} / \mathrm{dag}$. Enginn sjúklingur fékk samsetta meðferð með báđum veirulyfjum.

\begin{tabular}{|c|c|}
\hline Meðferð & fjöldi=n (\%) \\
\hline Meðferð með BiPAP & $4(25 \%)$ \\
\hline Lentu síðar í öndunarvél \% & $3(75 \%)$ \\
\hline Meðferð í öndunarvél & $12(75 \%)$ \\
\hline Grúfulega & $3(25 \%)$ \\
\hline NO innöndun & $1(6 \%)$ \\
\hline $\begin{array}{l}\text { Tímalengd í öndunarvél } \\
\text { (dagar) }\end{array}$ & $12,5(1-52)$ \\
\hline Hjarta- og lungnavél (ECMO) & $2(12 \%)$ \\
\hline Blóðskilun & $3(19 \%)$ \\
\hline $\begin{array}{l}\text { Blóðprýstingshækkandi } \\
\text { lyfjameðferð }\end{array}$ & $11(69 \%)$ \\
\hline Veirulyfjameðferð & $16(100 \%)$ \\
\hline Oseltamivir & $14(88 \%)$ \\
\hline Zanamivir & $2(12 \%)$ \\
\hline Fjöldi daga á veirulyfjum & $10(5-24)$ \\
\hline Önnur sýklalyfjameðferð & $16(100 \%)$ \\
\hline Ceftriaxone & $7(44 \%)$ \\
\hline Azithromycin & $5(31 \%)$ \\
\hline Amoxicillin/clavulanic acid & $3(19 \%)$ \\
\hline Meropenem & $3(19 \%)$ \\
\hline Cefuroxime & $2(13 \%)$ \\
\hline Barksterameðferð & $7(44 \%$ \\
\hline
\end{tabular}

jarðar pegar vetur gekk í garð par. Pessi faraldur undirstrikar vel hve mismunandi heimsfaraldrar inflúensu eru. Pegar á heildina er litið hefur hann prátt fyrir allt verið tiltölulega mildur, en lagst mjög pungt á fremur ungt og frískt fólk í stað aldraðra sem árstíðabundnir faraldrar hrjá frekar. Gjörgæslulæknar hérlendis hafa vart áður séð fólk á besta aldri fá svo alvarlega lungnabólgu af völdum veira og fáheyrt er að fá 16 slíka sjúklinga inn á gjörgæsludeild á svo stuttum tíma.

Pað er áberandi í pessum faraldri hve hátt hlutfall sjúklinga sem parf spítalainnlögn parf gjörgæslumeðferð, eða milli 10 og 20\%. Hins vegar eru 170 spítalainnlagnir, miðað við að 60100 púsund manns hafi veikst, fremur lágt hlutfall og í raun lægra en búast má við í árstíðabundinni inflúensu. ${ }^{17}$ Pá er heildardánartíðnin lægri nú en við árstíðabundna inflúensu par sem gert er ráð fyrir um $0,1 \%$ dánartíðni. ${ }^{18}$ Pað sem greinir pennan faraldur frá árstíðabundinni inflúensu er að nú veiktust einkum ungir og miðaldra, frískir einstaklingar í stað aldraðra og fjölveikra.

Sjúkdómurinn leggst pyngra á karla en konur á Íslandi ólíkt pví sem sést hefur í niðurstöðum annarra rannsókna, til dæmis í Kanada par sem tíðnin var hærri hjá konum. ${ }^{14}$ Pessi háa tíðni hjá körlum á Íslandi er pó í samræmi við upplýsingar frá Spáni, ${ }^{19}$ svo og við aðrar alvarlegar sýkingar. раð er til dæmis pekkt að körlum er hættara við að fá sýklasóttarlost en konum og peir deyja líka frekar af völdum pess en konur. ${ }^{20,21}$

Offita virðist vera áberandi áhættupáttur hjá íslenskum gjörgæslusjúklingum með inflúensu H1N1 eins og hjá öðrum pjóðum ${ }^{12-14}$ pví líkamspyngdarstuðull (BMI) var að meðaltali 31. Ekki er ljós ástæða pessarar auknu áhættu offeitra, en ýmsir pættir hafa verið nefndir, svo sem verri horfur offeitra með alvarlega sjúkdóma almennt og minnkað mótstöðuafl gegn sýkingum vegna breytinga í ónæmissvörun. ${ }^{22-24}$ Pá er hugsanlegt að minni lungnarýmd hjá peim sem eru offeitir skipti máli og leiði til pess að lungun séu viðkvæmari fyrir pessari sýkingu. ${ }^{24}$ Á hinn bóginn benda rannsóknir til að offita auki ekki hættu á dauða almennt hjá gjörgæslusjúklingum, heldur pvert á móti bæti horfur. ${ }^{25}$ Auk offitu var hátt hlutfall peirra sem lögðust inn á gjörgæslu með sögu um reykingar og háprýsting (tafla II). Рað sem virðist skilja íslenska gjörgæslusjúklinga sérstaklega frá erlendum sjúklingum er að peir voru flestir á aldrinum 30-60 ára en erlendis er tíðnin svipuð hjá öllum aldurshópum frá barnsaldri upp í sextugt. ${ }^{14}$ Hugsanlega hafði gott aðgengi að inflúensulyfjum á Íslandi verndandi áhrif. Pá virðist tíðni mjög alvarlegra veikinda sem purfa gjörgæslumeðferðar við heldur hærri hjá Íslendingum en hjá peim 
Tafla V. Samanburður á íslenskum niðurstöðum við samantektir annarra pjóða á gjörgæslusjúklingum með H1N1 inflúensu 2009.

\begin{tabular}{|c|c|c|c|c|c|c|c|}
\hline \multicolumn{8}{|l|}{ Samanburður við önnur lönd } \\
\hline Heimild (númer) & Ísland & $\begin{array}{l}\text { Nýja-Sjáland og } \\
\text { Ástralía (13) }\end{array}$ & $\begin{array}{l}\text { Spánn } \\
\text { (19) }\end{array}$ & $\begin{array}{c}\text { Kanada } \\
\text { (14) }\end{array}$ & $\begin{array}{l}\text { Mexíkó } \\
\text { (34) }\end{array}$ & $\begin{array}{l}\text { Mexíkó } \\
\text { (12) }\end{array}$ & $\begin{array}{l}\text { Chíle } \\
\text { (35) }\end{array}$ \\
\hline Fjöldi sjúklinga í rannsókn & 16 & 722 & 32 & 168 & 58 & 18 & 75 \\
\hline \multicolumn{8}{|l|}{ Meðalaldur } \\
\hline miốgildi & 48 & 40 & 36 & & 44 & 38 & 45 \\
\hline meðaltal & 46 & & & 32 & & & \\
\hline APACHE II (meðaltal) & 20 & & 14 & 20 & 20 & 15 & 14 \\
\hline Hlutfall karla & $75 \%$ & $48 \%$ & $73 \%$ & $33 \%$ & $47 \%$ & $50 \%$ & $59 \%$ \\
\hline Hlutfall barna & $6 \%$ & & & $30 \%$ & & $28 \%$ & \\
\hline Hlutfall sjúkrahúsinnlagna sem purfa gjörgæslu & $10-20 \%$ & & & $19 \%$ & $6,5 \%$ & & $5 \%$ \\
\hline \multicolumn{8}{|l|}{ Legutími } \\
\hline Dagar frá upphafi veikinda að innlögn (miðgildi) & 4 & 4 & 4 & 4 & & 6 & 5 \\
\hline Legutími á gjörgæslu (dagar, miðgildi) & 10 & 7 & & 12 & $14^{*}$ & & \\
\hline Legutími á sjúkrahúsi (dagar, miðgildi) & 16 & 12 & & 12 & & & \\
\hline Hlutfall ófrískra kvenna af gjörgæslusjúklingum & $0 \%$ & $9 \%$ & $6 \%$ & $8 \%$ & & & 9 \\
\hline Öndunarvélameðferð & $75 \%$ & $65 \%$ & $69 \%$ & $81 \%$ & $83 \%$ & $67 \%$ & $75 \%$ \\
\hline Tími öndunarvélameðferðar (dagar, miðgildi) & 13 & 8 & 10 & 12 & $15^{*}$ & & \\
\hline Hjarta- og lungnavél (ECMO) & $12 \%$ & $12 \%$ & 0 & $4 \%$ & 0 & & $6 \%$ \\
\hline Blóðskilun & $19 \%$ & & $22 \%$ & & & & $9 \%$ \\
\hline Dánartí̋ni & $6 \%$ & $14 \%$ & $19 \%$ & $14 \%$ & $40 \%$ & $39 \%$ & \\
\hline
\end{tabular}

*Gildi byggt á miðgildi sjúklinga sem lifðu af gjörgæslulegu.

pjóðum sem pegar hafa birt tölur um slíkt. ${ }^{12-14}$

Sjúklingar peir sem lögðust inn á sjúkrahús höfðu flestir haft einkenni í prjá til fjóra daga og peir sem voru lagðir inn á gjörgæsludeild höfðu að meðaltali legið inni á sjúkrahúsi í einn sólarhring fyrir innlögn á gjörgæsludeild. Sex sjúklinganna voru pó pað veikir að peir fóru beint á gjörgæslu eftir komu á spítala. Peir sem pörfnuðust gjörgæslumeðferðar veiktust flestir mjög alvarlega og lágu margir í tvær til prjár vikur á gjörgæsludeild og sumir lengur. Öndunarbilun vegna útbreiddrar lungnabólgu og bráðs andnauðarheilkennis (acute respiratory distress syndrome, ARDS) var mest áberandi og purftu flestir sjúklingarnir ekki eingöngu hefðbundna öndunarvélameðferð heldur einnig svokallaða viðbótarmeðferð. Viðbótarmeðferð, eins og grúfulegu í öndunarvél, fullri vöðvalömun, níturoxíð innöndun (nitric oxide) eða hjarta- og lungnavél (ECMO, extra corporeal membrane oxygenation) var beitt pegar ekki nægði að gefa sjúklingum $80 \%$ súrefni með hefðbundinni svokallaðri lungnaverndandi öndunarvélameðferð til að halda uppi viðunandi súrefnismettun í blóði. Lungnaverndandi öndunarvélameðferð felst í að takmarka prýsting í öndunarvegum $(<30$ $\left.\mathrm{cm} \mathrm{H}_{2} \mathrm{O}\right)$, takmarka rúmmál andardráttar $(<6$ $\mathrm{ml} / \mathrm{kg}$ ), nota hæfilegan prýsting í lok útöndunar (PEEP, positive end expiratory pressure) og forðast notkun á meira en $80 \%$ súrefni. Áberandi vandamál hjá pessum sjúklingum var mikið og seigt slím í berkjum sem ekki náðist upp við venjulega berkjusogun. Stundum var pví nauðsynlegt að hreinsa öndunarvegi með berkjuspeglun, jafnvel daglega.

Pótt öndunarbilun hafi verið mest áberandi hjá sjúklingunum á gjörgæsludeild sýndu margir peirra merki um truflanir á starfsemi annarra líffæra, svo sem bráđa nýrnabilun, sýklasóttarlost og truflun á storkukerfi eða meltingarvegi. ${ }^{23-}$ 24 Prír sjúklinganna sem urðu fyrir truflun á nýrnastarfsemi purftu á stöðugri blóðskilun að halda. Hjá einum peirra lagaðist nýrnastarfsemi, en hinir tveir fengu langvarandi nýrnaskaða (Loss class samkvæmt RIFLE skilmerkjum). Ólíkt peim sem fá bráđa nýrnabilun eftir sýklasótt virðast inflúensusjúklingarnir sjaldnast hafa orðið fyrir vökvaskorti eða blóðprýstingsfalli. Truflun í nýrnastarfsemi er vel pekkt í tengslum við inflúensusýkingar og stafar mögulega, ${ }^{26}$ að minnsta kosti að hluta til, af vöðvaniðurbroti (rhabdomyolysis) með tilheyrandi hækkun á kreatínkínasa og mýóglóbíni í sermi. Miklir beinverkir og vöðvaverkir hafa verið áberandi í pessum inflúensufaraldri og hefur háum kreatínkínasa gildum verið lýst í tengslum við inflúensu af stofni A. ${ }^{27,}{ }^{28}$ Mýoglóbín í sermi var mælt hjá einum sjúklingi og reyndist hækkað en 
kreatínkínasagildi var mælt hjá sjö sjúklingum og reyndist hækkað hjá peim öllum.

Nokkrir sjúklinganna voru með talsverða lækkun á blóðflögum og rauðum og hvítum blóðkornum við komu. Líklega voru petta merki um beinar afleiðingar veirusýkingarinnar og mergbælingu pótt pað hafi ekki verið kannað sérstaklega. Einnig var blæðingartilhneiging aukin hjá nokkrum sjúklingum, oftar en ekki prátt fyrir eðlileg eða nær eðlileg storkupróf. Blæðingar frá stungustöðum, undir húð, í lungum, frá meltingarvegi og pvagvegum voru algengastar.

Einkenni frá meltingarvegi voru einkum langvarandi parmalömun pannig að margir sjúklinganna höfðu engar hægðir í tvær til prjár vikur. Einnig komu blæðingar frá maga fyrir prátt fyrir gjöf prótónpumpuhemla og gjöf næringar í meltingarveg, en magablæðingar er nú sjaldgæfar hjá öðrum gjörgæslusjúklingum.

Enginn sjúklingur lést á gjörgæsludeild, en einn aldraður sjúklingur með fjölda alvarlegra undirliggjandi sjúkdóma lést á legudeild nokkrum dögum eftir útskrift af gjörgæslu. Meðaltals APACHE II skor var hátt, eða 20, sem sýnir að íslensku sjúklingarnir voru mjög veikir enda er áætluð dánartíðni samkvæmt APACHE II um $35 \%$ (tafla V). Pegar petta er skrifað eru allir sjúklingarnir útskrifaðir af gjörgæsludeild og allir nema einn (enn á lungnadeild) útskrifaðir af sjúkrahúsinu.

Ekki er ljóst af hverju tíðni alvarlegra einkenna er hærri á Îslandi en í Ástralíu, Nýja-Sjálandi og Kanada miðað við höfðatölu. Hugsanleg skýring getur verið hlutfallslega stærri faraldur, en erfðafræðilegir pættir gætu líka skipt máli. ${ }^{29}$

Eins og dæmigert er fyrir smitandi öndunarfærasjúkdóma fer sjúkdómurinn hratt yfir eins og lýst hefur verið í fyrri faröldrum bæði innan og milli landa. Í Mexíkó, Ástralíu, Nýja Sjálandi og Kanada stóð pað versta yfir í átta til tíu vikur ${ }^{12-14}$ eða svipað og kemur fram í pessari rannsókn, átta vikur.

Allir peir sjúklingar sem teknir voru með î pessari rannsókn voru með dæmigerð einkenni og jákvæð sýni um inflúensu A (H1N1). Eftirtektarvert var að hjá nokkrum sjúklingum voru fyrstu hálsstrokin neikvæð fyrir inflúensu A (NH1N1), en pegar sýni frá berkjuslími (eftir barkapræðingu) var rannsakað pá reyndist pað jákvætt. Eftirtektarvert var einnig hversu lengi sumir sjúklinganna reyndust jákvæðir prátt fyrir veirulyfjameðferð. Vegna pessa voru nokkrir sjúklingar hafðir í einangrun í allt að tvær vikur og meðferð með veirulyfjum var framlengd í 10-14 daga.

Gjörgæslumeðferð við inflúensu A hefur í yfirstandandi faraldri verið mjög kostnaðarsöm pví margir sjúklinganna hafa verið pað veikir að purfthefuráöllumtiltækummeðferðarmöguleikum gjörgæslulækninga að halda til að fleyta peim yfir erfiðasta hjallann. Í sumum tilfellum var kostnaðurinn á annan tug milljóna króna á sjúkling. Prátt fyrir mikinn kostnað réttlætir tiltölulega lágur meðalaldur pessara sjúklinga og miklar líkur á bata slíka meðferð. Flestir sjúklingarnir hafa, að pví er virðist, náð fullum bata miðað við fyrra ástand.

Á undanförnum árum hefur verið talsvert rætt um hugsanlega tregðu í pátttöku heilbrigðisstarfsmanna í umönnun sjúklinga á heimsfaraldurstímum. ${ }^{30-33}$ Ekki komu upp slík vandamál meðal starfsfólks á gjörgæsludeildum Landspítala eða Sjúkrahússins á Akureyri í núverandi heimsfaraldri. Pvert á móti var starfsfólkið sérstaklega ósérhlífið og æðrulaust og lagði sig fram um að sinna peim vandamálum sem komu upp. Farið var eftir leiðbeiningum um einangrun sjúklinga, notkun hlífðarbúnaðar og varast var að nota meðferðarúrræði sem gætu hugsanlega aukið á smithættu. Starfsfólkið var bólusett jafnskjótt og bóluefni barst til landsins. Ekki er vitað til að neinn starfsmanna ofangreindra deilda hafi veikst alvarlega.

Svo virðist sem faraldurinn, hvað varðar innlagnir gjörgæslusjúklinga, hafi verið styttri og snarpari hér en í öðrum löndum, en hámarki fjölda innlagna var náð fimm vikum eftir að fyrsti sjúklingurinn var lagður inn á gjörgæslu, en í Ástralíu/Nýja Sjálandi var tímalengd að hámarki innlagna sjö til átta vikur. ${ }^{13}$ Mikið munar um að meðhöndla 16 svo alvarlega veika sjúklinga á gjörgæsludeild til viðbótar við aðra sjúklinga, einkum par sem legutíminn var langur. Snemma varð ljóst að bæta pyrfti tækjakost deildanna og brugðust stjórnvöld hratt við og veittu fjármuni til pess, meðal annars voru keyptar sprautudælur til lyfjagjafa og hjarta- og lungnavélum, sem voru notaðar við ECMO-meðferð veikustu sjúklinganna í pessum faraldri, fjölgað um tvær.

Vegna viðbúnaðar pegar SARS-faraldurinn gekk yfir var öndunarvélarkostur gjörgæsludeildanna endurnýjaður og kom pað sér vel í pessum faraldri. Sýnir pað hve mikilvægt pað er að sýna fyrirhyggju og endurnýja og bæta tækjabúnað stöðugt.

Styrkur pessarar rannsóknar er einkum í pví fólginn að hún nær til allra sjúklinga sem lögðust inn á gjörgæsludeildir á öllu Íslandi vegna H1N1 inflúensu haustið 2009 og pess vegna einstök sinnar tegundar í heiminum. Ennfremur er petta fyrsta rannsóknin sem lýsir einkennum sjúkdómsins hjá Íslendingum, en 
pau virðast nokkuð frábrugðin peim sem lýst er 1́ erlendum rannsóknum. Veikleiki rannsóknarinnar er einkum fólginn í takmörkuðum fjölda sjúklinga sem dregur úr styrk niðurstaðna og möguleikum til ályktana.

\section{Ályktanir}

1. 16 sjúklingar með staðfesta inflúensu A(H1N1) purftu gjörgæslumeðferð í nýafstöðnum faraldri.

2. Sjúklingar sem leggjast inn á gjörgæsludeildir vegna H1N1 inflúensu á Íslandi fá auk annarra líffæratruflana flestir mjög alvarlega öndunarbilun, sem í mörgum tilfellum lætur ekki undan hefðbundinni lungnaverndandi öndunarvélameðferð.

3. Мeð peim viðbótarúrræðum sem tiltæk eru á íslenskum gjörgæsludeildum hefur árangur meðferðar hjá pessum veikustu sjúklingum pó hingað til verið góður og sjúklingarnir tiltölulega ungir og pví réttlætanlegt að leggja út í pann mikla kostnað sem pessi flókna meðferð felur í sér.

4. Niðurstöðurnar ættu að geta nýst yfirvöldum við mat á pörf áframhaldandi fyrirbyggjandi meðferðar með fjöldabólusetningum við pessum lífshættulega sjúkdómi.

5. Niðurstöðurnar ættu ennfremur að geta nýst við meðferð á sjúklingum sem sýkjast í annarri bylgju pessa H1N1 faraldurs, sem er hugsanlegt að gangi yfir á næstu mánuðum.

6. Draga má lærdóm af niðurstöðum rannsóknarinnar við gerð viðbragðsáætlana við síðari faröldrum.

\section{Heimildir}

1. Wright PF, Neumann G, Kawaoka Y. Í: Fields virology. Ritstiórar: Knipe DM, Howley PM. Lippincott Williams \& Wilkins. Philadelphia, Fifth Edition 2006: 1691-740.

2. Palese P, Shaw MLÍ. Fields virology. Ritstjórar: Knipe DM, Howley PM. Lippincott Williams \& Wilkins. Philadelphia, Fifth Edition 2006: 1647-90.

3. Potter CW. Í: Textbook of Influenza. Ritstjórar: Nicholson KG, Webster RG, Hay AJ. Blackwell Scientific, Oxford. 1998: 3-18.

4. Gottfreðsson M. Spænska veikin á Íslandi 1918. Lærdómur í læknisfræði og sögu. Læknablaðið 2008; 94: 737-45.

5. Johnson NP, Mueller J. Updating the accounts: global mortality of the 1918-1920 "Spanish" influenza pandemic. Bull Hist Med 2002; 76: 105-15.

6. Simonsen L, Clarke MJ, Schonberger LB, Arden NH, Cox NJ, Fukuda K. Pandemic versus epidemic influenza mortality: a pattern of changing age distribution. J Infect Dis. 1998; 178: 53-60.

7. World Health Organization. www.who.int/csr/don/2009 04_24/en/index.html, apríl 2009.

8. Centers for Disease Control and Prevention (CDC), MMWR cdc.gov $/ \mathrm{mmwr} /$ preview/mmwrhtml/mm5815a5.htm, apríl 2009.
9. Smith GJ, Vijaykrishna D, Bahl J, et al. Origins and evolutionary genomics of the 2009 swine-origin H1N1 influenza A epidemic. Nature 2009; 459: 1122-6.

10. Garten RJ, Davis CT, Russell CA, et al. Antigenic and genetic characteristics of swine-origin 2009 A(H1N1) influenza viruses circulating in humans. Science 2009; 325: 197-201.

11. Farsóttarfréttir, sóttvarnarlæknir. www.landlaeknir.is/ lisalib /getfile.aspx?itemid=4281, nóvember 2009.

12. Domínguez-Cherit G, Lapinsky SE, Macias AE, et al. Critically ill patients with 2009 influenza A (H1N1) in Mexico. JAMA 2009, 302: 1880-7.

13. The ANZIC Influenza Investigators. Critical Care Services and 2009 H1N1 Influenza in Australia and New Zealand. N Engl J Med 2009; 361: 1-10.

14. Kumar A, Zarychanski R, Pinto $R$, et al. Canadian Critical Care Trials Group H1N1 Collaborative. Critically ill patients with 2009 influenza A(H1N1) infection in Canada. JAMA 2009; 302: 1872-9.

15. Strand K, Flaatten H. Severity scoring in the ICU. Acta Anaesthesiol Scand 2008; 52467-78.

16. Farsóttarfréttir www.landlaeknir.is/lisalib/getfile. aspx?itemid=4037, desember 2009.

17. Jansen AG, Sanders EA, Hoes AW, van Loon AM, Hak E. Influenza- and respiratory syncytial virus-associated mortality and hospitalisations. Eur Respir J 2007; 30: 115866.

18. Thompson WW, Weintraub E, Dhankhar P, et al. Estimates of US influenza-associated deaths made using four different methods. Influenza Other Respi Viruses 2009; 3: 37-49.

19. Rello J, Rodríguez A, Ibañez P, et al. Intensive care adult patients with severe respiratory failure caused by Influenza A (H1N1)v in Spain. Crit Care 2009; 13: R148.

20. Kumar A, Roberts D, Wood KE, et al. Duration of hypotension before initiation of effective antimicrobial therapy is the critical determinant of survival in human septic shock. Crit Care Med 2006; 34: 1589-96.

21. Martin GS, Mannino DM, Eaton S, Moss M. The epidemiology of sepsis in the United States from 1979 through 2000. N Engl J Med 2003; 348: 1546-54.

22. Vaillant G, Tarantola A, Barboza P. Epidemiology of fatal cases associated with pandemic H1N1 influenza 2009. Euro Surveill 2009; 20: 14. pii:19309.

23. Rothberg MB, Haessler SD. Complications of seasonal and pandemic influenza. Crit Care Med. 2009 Nov 23. [Epub ahead of print]

24. Mancuso P. Obesity and Lung Inflammation. J Appl Physiol 2009 Oct 29. [Epub ahead of print]

25. Hogue CW Jr, Stearns JD, Colantuoni E, et al. The impact of obesity on outcomes after critical illness: a meta-analysis. Intensive Care Med 2009; 35: 1152-70.

26. Crum-Cianflone NF. Bacterial, fungal, parasitic, and viral myositis. Clin Microbiol Rev 2008; 21: 473-94.

27. Morton SE, Mathai M, Byrd RP, Fields CL, Roy TM. Influenza A pneumonia with rhabdomyolysis. South Med J 2001; 94 : 67-9.

28. Ayala E, Kagawa FT, Wehner JH, Tam J. Rhabdomyolysis associated with 2009 influenza A(H1N1). JAMA 2009; 302: $1863-4$.

29. Centers for Disease Control and Prevention (CDC). Serum cross-reactive antibody response to a novel influenza A (H1N1) virus after vaccination with seasonal influenza vaccine. MMWR Morb Mortal Wkly Rep 2009; 58: 521-4

30. Gardiner D. Are you coming to work during pandemic flu? Anaesthesia 2008; 63: 803-5.

31. Malm H, May T, Francis L, Omer S, Salmon D, Hood R. Ethics, pandemics, and the duty to treat. Am J Bioethics 2008; 8: 4-19.

32. Ruderman C, Tracy C, Bensimon C, et al. On pandemics and the duty to care: whose duty? who cares? BMC Med Ethics 2006; 7: 5-6.

33. Pahlman I, Tohmo H, Gylling H. Pandemic influenza: human rights, ethics and duty to treat. Acta Anaesthesiol Scand 2009 Nov 16. [Epub ahead of print].

34. Perez-Padilla R, de la Rosa-Zamboni D, Ponce de Leon S, et al. Pneumonia and respiratory failure from swine-origin influenza A (H1N1) in Mexico. N Engl J Med 2009; 361: 6809.

35. Ugarte S, Arancibia F, Soto R. Influenza A pandemics: Clinical and organizational aspects: The experience in Chile. Crit Care Med 2009 Nov 23. [Epub ahead of print]. 


\section{Intensive care patients with influenza A (H1N1) infection in Iceland 2009}

Background: We describe the main characteristics of patients that required intensive care due to the influenza (H1N1) outbrake in 2009.

Methods: Retrospective and prospective analysis of medical records from patients admitted to ICU with positive RT-PCR for (H1N1).

Results: During a six week period in the fall of 2009, 16 patients were admitted to intensive care in Iceland with confirmed $\mathrm{H} 1 \mathrm{~N} 1$ infection. Mean age was 48 years (range 1-81). Most patients were considered quite healthy but the majority had risk factors such as smoking, obesity or hypertension. All but one had fever, cough, dyspnea and bilateral infiltrates on chest x-ray and developed any organ failures (mean SOFA score 7). 12 needed mechanical ventilation and two extra corporeal membrane oxygenation (ECMO). Mean APACHE II score was 20. No patient died in the ICU but one elderly patient with multiple underlying diseases died a few days after being discharged from the ICU.

Conclusions: (1) The incidence of severe influenza A (H1N1) that leads to ICU admission appears to be high in Iceland. (2) Many patients developed acute respiratory distress syndrome in addition to other organ failures, and required additional measures for oxygenation such as prone position, nitric oxide inhalation and ECMO. (3) 28 day mortality was low. (4) This study will aid in future outbreak planning in Iceland.

Sigurdsson GH, Möller AD, Kristinsson B, Gudlaugsson O, Karason S, Sigurdsson SE, Kristjansson M, Sigvaldason K.

Intensive care patients with influenza A (H1N1) infection in Iceland 2009. Icel Med J 2010; 83-90

Key words: influenza A, pneumonia, multiple organ failure, death rate, intensive care, ventilator therapy, ECMO.

Correspondence: Gísli H. Sigurðsson, gislihs@landspitali.is

Barst: 4. desember 2009, - sampykkt til birtingar: 14. janúar 2010 Hagsmunatengsl höfunda: Engin 